\title{
EVALUATION OF THETOXICITY OF SYNTHETIC PYRETHROIDSTO RED SWAMP CRAYFISH (PROCAMBARUS CLARKII, GIRARD 1852) AND COMMON CARP (CYPRINUS CARPIO, L. 1758)
}

\author{
C. MOROLLI(1), F. QUAGLIO(2), G. DELLA ROCCA(3), J. MALVISI(3), A. DI SALVO(3)
}

(1) Dipartimento di Scienze degli Alimenti - Università degli Studi di Bologna, Via S. Giacomo 9, 40126 Bologna, Italy. E-Mail: cmorolli@cren.it

(2) Dipartimento di Sanità Pubblica patologia Comparata ed Igiene Veterinaria, Università di Padova, Agripolis, V. le dell'Università, 1635020 Legnaro (PD), Italy.

(3) Dipartimento di Patologia, Diagnostica e Clinica Veterinaria, Sez. Sc. Sperim. e Biotecn. Appl., Università degli Studi di Perugia, Via S. Costanzo, 406126 Perugia, Italy

Reçu le 16 juin 2005

Accepté le 24 janvier 2006

Received June 16, 2005 Accepted January 24, 2006

\section{ABSTRACT}

The acute toxicity of three synthetic pyrethroids (Cypermethrin, Deltamethrin and Cyfluthrin) to red swamp crayfish (Procambarus clarkii) and the mortality after long-term exposition of young common carp to Deltamethrin were determined in standardized laboratory tests.

The aim of this study was to evaluate the possibility of limiting the expansion of crayfish by the use of these compounds and the implications of their use on fish.

Red swamp crayfish experienced high sensitivity to pyrethroids as expressed by the LC50-24h: $0.14 \mu \mathrm{g} / \mathrm{l}$ for Cypermethrin, $0.17 \mu \mathrm{g} / \mathrm{l}$ for Cyfluthrin and $0.22 \mu \mathrm{g} / \mathrm{l}$ for Deltamethrin. No mortality was observed in common carp during the long term (24 days) exposure test at initial concentration of $22.0 \mu \mathrm{g} / \mathrm{l}$ of Deltamethrin. The concentrations of Deltamethrin in muscle of crayfish and common carp were under the limit of quantification of the gas-chromatographic method in all the tests.

The results suggest that synthetic pyrethroids may be suitable to control or to eradicate nuisance populations of red swamp crayfish, in small and limited areas.

Key-words: red swamp crayfish, Procambarus clarkii, common carp, Cyprinus carpio, pyrethroids, toxicity.

\section{ÉVALUATION DE LATOXICITÉ DE PYRÉTHROÏDES SYNTHÉTIQUES SUR LES ÉCREVISSES ROUGES DES MARAIS DE LOUISIANE (PROCAMBARUS CLARKII, GIRARD 1852) ET SUR LA CARPE COMMUNE (CYPRINUS CARPIO, L. 1758)}

\section{RÉSUMÉ}

La toxicité aiguë de trois pyréthroïdes synthétiques (cyperméthrine, deltaméthrine et cyfluthrine) sur les écrevisses rouges de marais (Procambarus clarkii) et la mortalité après exposition de jeunes carpes communes (Cyprinus carpio) à la deltaméthrine pendant une longue période, ont été déterminées lors d'essais normalisés en laboratoire. 
Le but de cette étude était d'évaluer la possibilité d'utiliser ces composés pour limiter l'expansion des écrevisses et les implications de leur utilisation sur des poissons.

Les écrevisses rouges de marais ont manifesté une sensibilité élevée aux pyréthroïdes, comme l'exprime le LC50-24h: 0,14 $\mu \mathrm{g} / \mathrm{l}$ pour la cyperméthrine, $0,17 \mu \mathrm{g} / \mathrm{l}$ pour la cyfluthrine et $0,22 \mu \mathrm{g} / \mathrm{l}$ pour la deltaméthrine. On n'a observé aucune mortalité de carpe commune lors de l'essai avec une longue période d'exposition (24 jours) à la concentration initiale de $22,0 \mu \mathrm{g} / \mathrm{l}$ de deltaméthrine. Les concentrations de deltaméthrine dans le muscle des écrevisses et dans les carpes communes se trouvaient toujours en dessous de la limite de quantification de la méthode de chromatographie gazeuse.

Les résultats suggèrent que des pyréthroïdes synthétiques peuvent être adoptés pour contrôler ou supprimer des populations nuisibles d'écrevisses rouges de marais dans des zones limitées et localisées.

Mots-clés : écrevisses rouges de marais de Louisiane, Procambarus clarkii, carpe commune, Cyprinus carpio, pyréthroïdes, toxicité.

\section{INTRODUCTION}

The rapid expansion of red swamp crayfish populations in the inland waters of Emilia Romagna Region (Italy) causes several types of damage to the natural ecosystem and to the agriculture.

In fact this NICS (Non Indigenous Crayfish Species) finds a favourable habitat in the marsh and wet areas of lowland, reaching a very high density of population; QUAGLIO et al. (2000) estimated a population density of 8.2 specimen $/ \mathrm{m}^{2}$ in a channel in the Bologna province.

As a burrowing species, red swamp crayfish may disrupt the irrigation networks, damaging earthen dykes and levees, which are important in fish rearing and agriculture. Moreover, they increase the turbidity of water, reducing photosynthesis in submerged plants.

By eating aquatic plants, eggs and young of fish and amphibians, crayfish disturb the endemic aquatic fauna and the equilibrium of the aquatic ecosystems.

In fish hatcheries red swamp crayfish interfere with the seining, harvesting and sorting of fish. They can eat the food for fish and disturb the normal growth and reproduction of fish.

Crayfish occasionally eat rice seeds and seedlings, and their digging can also uproot seedlings.

Thus, in conditions of high crayfish density, eradication or control of populations is necessary and urgent.

HOLDICH, GYDEMO and ROGERS (1999) presented a review of possible methods for controlling nuisance populations of alien crayfish and divided the methods to the five broad categories:

- Legislative: local and national regulations.

- Mechanical: control by hand or with traps.

- Biological: parasites, disease and predators.

- Physical: temperature, environmental manipulation.

- Chemical: biocides, attractants, repelling agents. 
Unfortunately, the low impact methods (specific laws, trapping, biomanipulation of trophic web, etc.) are generally not effective and the application of toxic chemicals appears to be the only way to achieve some successful results.

The ideal pesticide should have:

- High target animal toxicity.

- Low toxicity to non-target animals.

- Stability and low accumulation in the environment.

Laboratory tests are necessary to verify the effects and the properties of natural or synthetic biocides on target and non target organisms, and they can give important information in order to hypothesize field treatments for the control or the eradication of non-indigenous crayfish species.

For this study we chose synthetic pyrethroids: a class of more than 1,000 powerful, broad-spectrum insecticides used to control insect pests in households, agriculture, forestry, aquaculture and stored products. They are based on the chemical structure and biological activity of natural pyrethrum, an extract from plants of the genus Chrysanthemum. Compared to natural pyrethrum they are:

- more toxic,

- less rapidly degraded by light,

- more readily available and

- cheaper

\section{MATERIAL AND METHODS}

\section{Acute toxicity tests on Procambarus clarkii}

Commercial formulations containing synthetic pyrethroids were used in the toxicity assays on P. clarkii: Responsar ${ }^{\circledR}$ SC (Bayer), containing $125 \mathrm{~g} / \mathrm{l}$ of $\beta$-Cyfluthrin (active ingredient), Percitox $25^{\circ}$ (INDIA) containing $2.5 \%$ of Cypermethrin (active ingredient) and DeltrinFlow (INDIA) containing $1 \%$ of Deltamethrin (active ingredient). The physicochemicals characteristics and the molecular structures of these pyrethroids are reported, respectively, in Tables I-III and in Figures 1-3.

A total of 800 adult red swamp crayfish (body size: 6-9.5 cm), used in the acute toxicity tests, were collected from canals and ditches in Modena and Bologna provinces (Emilia Romagna Region, Italy).

A screening was carried out to obtain an approximate indication of the range of the insecticides concentrations to be toxic on P. clarkii. Preliminary trials were conducted on 50 crayfish/each product with a series of five different dilutions from $2.5 \mu \mathrm{g} / \mathrm{l}$ to $0.01 \mu \mathrm{g} / \mathrm{l}$. The concentrations range for succeeding tests $(0.05-0.80 \mu \mathrm{g} / \mathrm{l})$ were derived from the interval of the dosage range in the preliminary test giving 0 $100 \%$ mortality.

Crayfish were held at least 2 weeks in 40 I plastic boxes with dechlorinated and aerated tap water to ensure the state of health before they would be tested, and daily fed "ad libitum" with pellets for fish. After this period, in which no mortality occurred, the following concentrations: $0 \mu \mathrm{g} / \mathrm{l}$ (control); $0.05 \mu \mathrm{g} / \mathrm{l} ; 0.10 \mu \mathrm{g} / \mathrm{l} ; 0.20 \mu \mathrm{g} / \mathrm{l} ; 0.40 \mu \mathrm{g} / \mathrm{l}$; $0.80 \mu \mathrm{g} / \mathrm{l}$, were tested on the crayfish. Each concentration was replicated in 5 different tests. 


\section{Table I}

Physicochemical properties of pure Deltamethrin.

\section{Tableau I}

Propriétés physico-chimiques de la Deltaméthrine.

\begin{tabular}{|l|l|}
\hline \multicolumn{2}{|c|}{ Deltamethrin } \\
\hline IUPAC chemical name & $\begin{array}{l}(S)-\alpha \text {-cyano-3-phenoxybenzyl(1R,3R)-3-(2,2-dibromovinyl)- } \\
2,2-\text {-dimethylcyclopropane Carboxylate }\end{array}$ \\
\hline Characteristic & \multicolumn{1}{c|}{ Value } \\
\hline Solubility in water & $2.0 \mu \mathrm{g} / \mathrm{l}, 25^{\circ} \mathrm{C}$ \\
\hline Hydrolysis characteristics & $\begin{array}{l}\text { Negligible hydrolysis at } 25^{\circ} \mathrm{C} \text { at } \mathrm{pH} 5 \\
\text { Negligible hydrolysis at } 25^{\circ} \mathrm{C} \text { at } \mathrm{pH} 7 \\
\text { Half-life }=2.5 \text { days at } 25^{\circ} \mathrm{C} \text { at } \mathrm{pH} 9\end{array}$ \\
\hline Photolysis characteristics & $\begin{array}{l}\text { Deltamethrin is directly phototransformed, } \mathrm{DT}_{50}=48 \text { days, } \\
\text { and indirectly photo-transformed, } \mathrm{DT}_{50}=4 \text { days. }_{50}\end{array}$ \\
\hline $\begin{array}{l}\text { Dissociation } \\
\text { characteristics }\end{array}$ & Does not dissociate. \\
\hline
\end{tabular}<smiles>CC1C(C=C(Br)Br)C(C)C1C(=O)O[C@H](C#N)c1cccc(Oc2ccccc2)c1</smiles>

\section{Figure 1}

Molecular structure of Deltamethrin.

\section{Figure 1}

Structure moléculaire de la Deltaméthrine. 


\section{Table II}

Physicochemical properties of Cypermethrin.

Tableau II

Propriétés physico-chimiques de la Cyperméthrine.

\begin{tabular}{|l|l|}
\hline \multicolumn{2}{|c|}{ Cypermethrin } \\
\hline IUPAC chemical name & $\begin{array}{l}\text { (RS)- } \alpha \text {-cyano-3-phenoxybenzyl(1RS)-cis,trans-3- } \\
(2,2-\text { dichlorovinyl)-2,2-dimethylcyclopropane Carboxylate }\end{array}$ \\
\hline Characteristic & \multicolumn{1}{c|}{ Value } \\
\hline Solubility in water & $4.0 \mu \mathrm{g} / \mathrm{l}, 20^{\circ} \mathrm{C}$ \\
\hline Hydrolysis characteristics & Half-life $>50$ days \\
\hline Photolysis characteristics & $\begin{array}{l}\text { In soil 8-16 days } \\
\text { In water }>100 \text { days }\end{array}$ \\
\hline Dissociation characteristics & Does not dissociate. \\
\hline
\end{tabular}

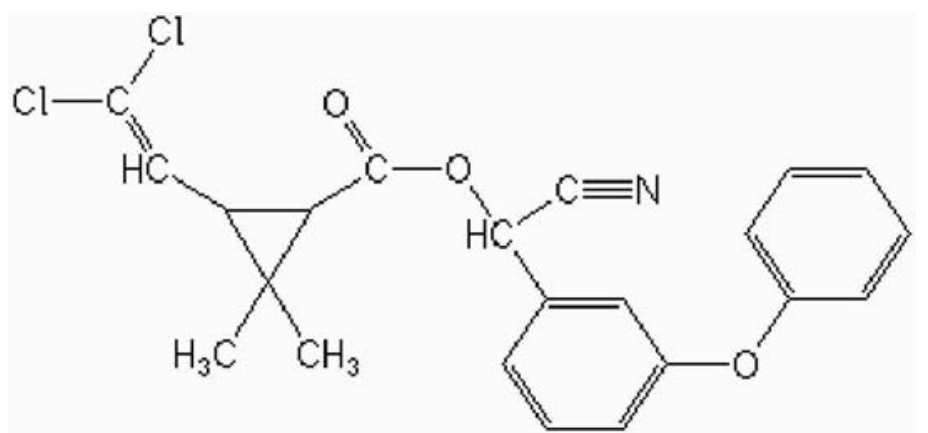

\section{Figure 2}

Molecular structure of Cypermethrin

\section{Figure 2}

Structure moléculaire de la Cyperméthrine. 


\section{Table III}

Physicochemical properties of pure Cyfluthrin.

Tableau III

Propriétés physico-chimiques de la Cyfluthrine pure.

\begin{tabular}{|c|c|}
\hline \multicolumn{2}{|r|}{ Cyfluthrin } \\
\hline $\begin{array}{l}\text { IUPAC chemical } \\
\text { name }\end{array}$ & $\begin{array}{l}\text { (RS)- } \alpha \text {-cyano-4-fluoro-3-phenoxybenzyl(1RS,3RS;1RS,3SR)-3- } \\
\text { (2,2-dichlorovinyl)-2,2-dimethylcyclopropane carboxylate }\end{array}$ \\
\hline Characteristic & Value \\
\hline $\begin{array}{l}\text { Solubility } \\
\text { in water }\end{array}$ & $\begin{array}{l}\text { Diastereoisomer I: } 2.5 / 2.2 \mu \mathrm{g} / \mathrm{l}(\mathrm{pH}=3 / \mathrm{pH}=7) \\
\text { Diastereoisomer II: } 2.1 / 1.9 \mu \mathrm{g} / \mathrm{l}(\mathrm{pH}=3 / \mathrm{pH}=7) \\
\text { Diastereoisomer III: } 3.2 / 2.2 \mu \mathrm{g} / \mathrm{l}(\mathrm{pH}=3 / \mathrm{pH}=7) \\
\text { Diastereoisomer IV: } 4.3 / 2.9 \mu \mathrm{g} / \mathrm{l}(\mathrm{pH}=3 / \mathrm{pH}=7) \\
\text { Solubility only slightly influenced by } \mathrm{pH}\end{array}$ \\
\hline $\begin{array}{l}\text { Hydrolysis } \\
\text { characteristics }\end{array}$ & $\begin{array}{l}\text { The material used was a defined mixture of the } 4 \text { diastereoisomeric } \\
\text { enantiomer pairs. (DT } \\
\text { Diastereoisomer I: } \mathrm{pH} 4,7 \text { and } 9 \text { at } 20^{\circ} \mathrm{C} \text { ) } \\
\text { Diastereoisomer } \mathrm{II}:>1 \text { year, } 270 \text { days, } 42 \text { hours } 42 \text { hours } \\
\text { Diastereoisomer III: }>1 \text { year, } 160 \text { days, } 33 \text { hours } \\
\text { Diastereoisomer IV: }>1 \text { year, } 160 \text { days, } 33 \text { hours }\end{array}$ \\
\hline $\begin{array}{l}\text { Photolysis } \\
\text { characteristics }\end{array}$ & $\begin{array}{l}\text { The material used was a defined mixture of the } 4 \text { diastereoisomeric } \\
\text { enantiomer pairs. } \\
\mathrm{DT}_{50} 12.2 \text { days in water. } \\
\mathrm{DT}_{50} 25.7 \text { hours in air. }\end{array}$ \\
\hline $\begin{array}{l}\text { Dissociation } \\
\text { characteristics }\end{array}$ & Cyfluthrin does not show basic or acidic properties in water. \\
\hline
\end{tabular}<smiles>CC1(C)C(C=C(Cl)Cl)C1C(=O)OC(C#N)c1ccc(F)c(Oc2ccccc2)c1</smiles>

\section{Figure 3}

Molecular structure of Cyfluthrin.

\section{Figure 3}

Structure moléculaire de la Cyfluthrine. 
Eight acclimatized crayfish (4 males and 4 females) were held in a 40 I plastic box with dechlorinated water in each treatment of the concentration series. The water temperature was $20^{\circ} \mathrm{C} \pm 1^{\circ} \mathrm{C}, \mathrm{pH} 7.9 \pm 0.1$ and the oxygen saturation was maintained during the assays by constant air diffusion. No feeding was delivered during the assay. The effects of pyrethroids on crayfish were periodically observed (5, 24, 48 hours). Dead crayfish were collected and registered and the mortalities expressed as percent mortality. Immobile crayfish were considered dead and removed immediately if they did not respond to probing with a glass rod.

For each replication we determined the LC50-24h and the LC50-48h according to LITCHFIELD and WILCOXON (1949) by the graphic method of the curve dose-effect, using the probit analysis. The data of each repetition were submitted to the statistical test $\chi^{2}$ and the confidence limits were calculated.

\section{Long term (24d) toxicity test on Cyprinus carpio}

A 24-day test to evaluate the long-term toxicity and the effects of Deltamethrin was carried out on common carp (Cyprinus carpio).

Forty-eight young carp (average weight $=23 \mathrm{~g}$ ) were allocated in a $500 \mathrm{I}$ plastic box containing dechlorinated and aerated tap water, a week before the test to aclimatize at the water's conditions. Before the test, Deltamethrin was added dissolved in water to reach a final concentration of $22.0 \mu \mathrm{g} / \mathrm{l}$ (one hundred time higher than the LC50-24h evaluated in this study for the crayfish).

\section{Evaluation of pyrethroid residues in fish and crayfish}

\section{Extraction and purification}

After the treatment with the three different pyrethroids, several samples of crayfish and fish (Table IV and Table V) were analysed to verify their accumulation in these tissues. From each sample, $2.5 \mathrm{~g}$ of tissue of muscle and adherent skin of Cyprinus carpio and portion of abdominal muscle of Procambarus clarkii were cut into small pieces and placed in $50 \mathrm{ml}$ plastic tubes (Falcon); then $5 \mathrm{ml}$ distilled water, $9 \mathrm{ml} \mathrm{n}$-hexane and $6 \mathrm{ml}$ acetone were added to the tube. The tissues were homogenised (Ultraturrax, Pabish s.r.l., Milan, Italy) for $1 \mathrm{~min}$, then $15 \mathrm{~g}$ of $\mathrm{Na}_{2} \mathrm{SO}_{4}$, anhydrous were added to the homogenate. The mixture was vortexed and centrifuged (ALC 4216, Apparecchi per Laboratori Clinici s.r.l., Milan, Italy) at $7,000 \mathrm{rpm}$ for $5 \mathrm{~min}$. The organic extract was filtered through a Whatman filter (GD/X Nylon $0.45 \mu \mathrm{m}, 22 \mathrm{~mm}$ ). The filtrate was evaporated to dryness under vacuum (Uniequip system, Uniequip Laborgerate, Martinsried, Germany). The residues was reconstituted with $1 \mathrm{ml} \mathrm{n}$-hexane and transferred on silica-gel column (Isolute silica $500 \mathrm{mg} / 6 \mathrm{ml})$, activated with $5 \mathrm{ml}$ of $\mathrm{n}$-hexane and $5 \mathrm{ml}$ of diethyl ether/n-hexane $(5 / 95 \mathrm{v} / \mathrm{v})$ for a clean-up. The pyrethroids were eluted with $10 \mathrm{ml}$ of diethyl ether/n-hexane (5/95 v/v), the eluate was dried and the residue was reconstituted with $500 \mu \mathrm{l}$ of $\mathrm{n}$-hexane for GC analysis.

\section{Chromatographic conditions}

A GC - Autosystem XL (Perkin Elmer instruments) equipped with a ${ }^{63} \mathrm{Ni}$ electroncapture detector and a capillary column Rtx-5MS, $30 \mathrm{~m} \times 0.25 \mathrm{~mm}$ ID, $0.25 \mu \mathrm{m}$ film from Superchrom (Bellefonte, PA, USA) was used. Operating conditions were as follows: initial temperature $100^{\circ} \mathrm{C}$, increased at $45^{\circ} \mathrm{C} / \mathrm{min}$ to $180^{\circ} \mathrm{C}$, held for $5 \mathrm{~min}$, then increased at $5^{\circ} \mathrm{C} / \mathrm{min}$ to $300^{\circ} \mathrm{C}$ for $20 \mathrm{~min}$; injector temperature $270^{\circ} \mathrm{C}$; carrier gas He; pressure $20 \mathrm{psi}$; detector temperature $370^{\circ} \mathrm{C}$; make-up gas $\mathrm{N}_{2}$; operated in splitless mode; purge off time $1 \mathrm{~min}$; injection volume $5 \mu \mathrm{l}$. 
Table IV

Results of evaluation of pyrethroid's residues in crayfish.

Tableau IV

Résultats de l'évaluation des résidus de pyréthroïdes sur les écrevisses.

\begin{tabular}{|l|l|l|c|l|}
\hline $\begin{array}{l}\text { Tested sinthetic } \\
\text { pyrethroid }\end{array}$ & Concentration & $\begin{array}{l}\text { Period of } \\
\text { treatment }\end{array}$ & $\begin{array}{l}\mathbf{N}^{\circ} \text { of analyzed } \\
\text { crayfish }\end{array}$ & Results \\
\hline Delthamehtrin & $0.22 \mu \mathrm{g} / \mathrm{l}$ & 24 hours & 5 & Each sample < LOQ \\
\hline Cyfluthrin & $0.17 \mu \mathrm{g} / \mathrm{l}$ & 24 hours & 7 & Each sample < LOQ \\
\hline Cypermethrin & $0.16 \mu \mathrm{g} / \mathrm{l}$ & 24 hours & 6 & Each sample < LOQ \\
\hline Delthamehtrin & $0.18 \mu \mathrm{g} / \mathrm{l}$ & 48 hours & 5 & Each sample < LOQ \\
\hline Cyfluthrin & $0.08 \mu \mathrm{g} / \mathrm{l}$ & 48 hours & 4 & Each sample < LOQ \\
\hline Cypermethrin & $0.10 \mu \mathrm{g} / \mathrm{l}$ & 48 hours & 4 & Each sample < LOQ \\
\hline
\end{tabular}

\section{Table V}

Results of evaluation of Deltamethrin residues in fish.

Tableau V

Résultats de l'évaluation des résidus de Deltaméthrine sur les carpes.

\begin{tabular}{|c|c|c|c|}
\hline $\begin{array}{c}\text { Long term toxicity test on Cyprinus carpio with Delthamehtrin } \\
\text { (initial concentration in tank = 22.00 } \boldsymbol{\mu g} / \mathbf{l} \text { ) }\end{array}$ \\
\hline Sample $\mathbf{n}^{\circ}$ & $\begin{array}{c}\text { Period of } \\
\text { treatment } \\
\text { (days) }\end{array}$ & $\begin{array}{c}\mathbf{N}^{\circ} \text { of } \\
\text { analyzed fish }\end{array}$ & Results \\
\hline 1 & 1 & 6 & $<\mathrm{LOQ}$ \\
\hline 2 & 2 & 6 & $<\mathrm{LOQ}$ \\
\hline 3 & 3 & 6 & $<\mathrm{LOQ}$ \\
\hline 4 & 5 & 6 & $<\mathrm{LOQ}$ \\
\hline 5 & 7 & 6 & $<\mathrm{LOQ}$ \\
\hline 6 & 10 & 6 & $<\mathrm{LOQ}$ \\
\hline 7 & 17 & 6 & $<\mathrm{LOQ}$ \\
\hline 8 & 24 & 6 & $<\mathrm{LOQ}$ \\
\hline
\end{tabular}

\section{Calibration curves and recoveries}

Stock solutions of deltamethrin, cyfluthrin and cypermethrin $(100 \mu \mathrm{g} / \mathrm{ml})$ were prepared in n-hexane and stored at $4^{\circ} \mathrm{C}$ in darkness. Calibration standards were prepared daily and run with each set of unknown samples. Slopes, intercepts and correlation coefficients were determined before each analytical session. Calibration curve concentrations from spiked tissues were in the range $0.01-1 \mathrm{ppm}$. Limits of quantification of the analytical method were $10 \mathrm{ppb}$ for cyfluthrin and cypermethrin and $50 \mathrm{ppb}$ for deltamethrin. The deltamethrin, cyfluthrin and cypermethrin concentrations in the unknown samples were calculated from the peak area by interpolation of the calibration curves. 


\section{RESULTS}

\section{Acute toxicity tests on Procambarus clarkii}

The results of LC50-24h and LC50-48h for each replication are summarized in TableVl; Figure 4 represents two dose-mortality curves for the calculation of lethal concentrations 50 of the examined pyrethroids in P. clarkii.

\section{Table VI}

Results of acute toxicity tests on crayfish, in each replication.

Tableau VI

Résultats des tests de toxicité aiguë sur les écrevisses, dans chaque réplicat.

\begin{tabular}{|c|c|c|c|c|c|c|c|c|c|}
\hline \multicolumn{10}{|c|}{ LC50 VALUES FOR SINGLE REPLICATION } \\
\hline \multicolumn{5}{|c|}{ CYPERMETHRIN } & \multicolumn{5}{|c|}{ CYPERMETHRIN } \\
\hline & \begin{tabular}{|l} 
Inferior \\
Fiducial \\
limit
\end{tabular} & $\begin{array}{l}\text { LC50- } \\
48 \mathrm{~h}\end{array}$ & $\begin{array}{l}\text { Superior } \\
\text { Fiducial } \\
\text { limit }\end{array}$ & & & $\begin{array}{l}\text { Inferior } \\
\text { Fiducial } \\
\text { limit }\end{array}$ & $\begin{array}{l}\text { LC50- } \\
48 \mathrm{~h}\end{array}$ & $\begin{array}{l}\text { Superior } \\
\text { Fiducial } \\
\text { limit }\end{array}$ & \\
\hline Replication 1 & 0.04 & 0.12 & 0.32 & $\mu g / l$ & Replication 1 & 0.03 & 0.08 & 0.24 & $\mu \mathrm{g} / \mathrm{l}$ \\
\hline Replication 2 & 0.07 & 0.15 & 0.34 & $\mu g / l$ & Replication 2 & 0.05 & 0.10 & 0.23 & $\mu \mathrm{g} / \mathrm{l}$ \\
\hline Replication 3 & 0.08 & 0.16 & 0.32 & $\mu \mathrm{g} / \mathrm{l}$ & Replication 3 & 0.05 & 0.11 & 0.23 & $\mu \mathrm{g} / \mathrm{l}$ \\
\hline Replication 4 & 0.05 & 0.12 & 0.28 & $\mu g / l$ & Replication 4 & 0.05 & 0.11 & 0.23 & $\mu \mathrm{g} / \mathrm{l}$ \\
\hline Replication 5 & 0.08 & 0.16 & 0.32 & $\mu g / l$ & Replication 5 & 0.05 & 0.10 & 0.23 & $\mu \mathrm{g} / \mathrm{l}$ \\
\hline AVERAGE & 0.08 & 0.16 & 0.32 & $\mu g / l$ & AVERAGE & 0.05 & 0.10 & 0.23 & $\mu \mathrm{g} / \mathrm{l}$ \\
\hline \multicolumn{5}{|c|}{ DELTAMETHRIN } & \multicolumn{5}{|c|}{ DELTAMETHRIN } \\
\hline & $\begin{array}{l}\text { Inferior } \\
\text { Fiducial } \\
\text { limit }\end{array}$ & $\begin{array}{l}\text { LC50- } \\
48 \mathrm{~h}\end{array}$ & $\begin{array}{l}\text { Superior } \\
\text { Fiducial } \\
\text { limit }\end{array}$ & & & $\begin{array}{l}\text { Inferior } \\
\text { Fiducial } \\
\text { limit }\end{array}$ & $\begin{array}{l}\text { LC50- } \\
48 \mathrm{~h}\end{array}$ & $\begin{array}{l}\text { Superior } \\
\text { Fiducial } \\
\text { limit }\end{array}$ & \\
\hline Replication 1 & 0.10 & 0.20 & 0.42 & $\mu g / l$ & Replication 1 & 0.06 & 0.15 & 0.35 & $\mu \mathrm{g} / \mathrm{l}$ \\
\hline Replication 2 & 0.13 & 0.25 & 0.47 & $\mu g / l$ & Replication 2 & 0.08 & 0.17 & 0.34 & $\mu \mathrm{g} / \mathrm{l}$ \\
\hline Replication 3 & 0.11 & 0.22 & 0.44 & $\mu g / l$ & Replication 3 & 0.09 & 0.18 & 0.37 & $\mu \mathrm{g} / \mathrm{l}$ \\
\hline Replication 4 & 0.11 & 0.20 & 0.38 & $\mu g / l$ & Replication 4 & 0.08 & 0.16 & 0.32 & $\mu \mathrm{g} / \mathrm{l}$ \\
\hline Replication 5 & 0.13 & 0.25 & 0.47 & $\mu g / l$ & Replication 5 & 0.12 & 0.22 & 0.38 & $\mu \mathrm{g} / \mathrm{l}$ \\
\hline AVERAGE & 0.12 & 0.22 & 0.44 & $\mu g / l$ & AVERAGE & 0.09 & 0.18 & 0.35 & $\mu \mathrm{g} / \mathrm{l}$ \\
\hline \multicolumn{5}{|c|}{ CYFLUTHRIN } & \multicolumn{5}{|c|}{ CYFLUTHRIN } \\
\hline & $\begin{array}{l}\text { Inferior } \\
\text { Fiducial } \\
\text { limit }\end{array}$ & $\begin{array}{l}\text { LC50- } \\
48 \mathrm{~h}\end{array}$ & $\begin{array}{l}\text { Superior } \\
\text { Fiducial } \\
\text { limit }\end{array}$ & & & $\begin{array}{l}\text { Inferior } \\
\text { Fiducial } \\
\text { limit }\end{array}$ & $\begin{array}{l}\text { LC50- } \\
48 \mathrm{~h}\end{array}$ & $\begin{array}{l}\text { Superior } \\
\text { Fiducial } \\
\text { limit }\end{array}$ & \\
\hline Replication 1 & 0.06 & 0.14 & 0.32 & $\mu g / l$ & Replication 1 & 0.03 & 0.08 & 0.19 & $\mu \mathrm{g} / \mathrm{l}$ \\
\hline Replication 2 & 0.09 & 0.18 & 0.34 & $\mu g / l$ & Replication 2 & 0.02 & 0.06 & 0.20 & $\mu \mathrm{g} / \mathrm{l}$ \\
\hline Replication 3 & 0.11 & 0.20 & 0.35 & $\mu g / l$ & Replication 3 & 0.04 & 0.09 & 0.21 & $\mu \mathrm{g} / \mathrm{l}$ \\
\hline Replication 4 & 0.07 & 0.14 & 0.29 & $\mu g / l$ & Replication 4 & 0.03 & 0.08 & 0.19 & $\mu g / l$ \\
\hline Replication 5 & 0.09 & 0.18 & 0.34 & $\mu g / l$ & Replication 5 & 0.04 & 0.08 & 0.19 & $\mu \mathrm{g} / \mathrm{l}$ \\
\hline AVERAGE & 0.08 & 0.17 & 0.33 & $\mu g / l$ & AVERAGE & 0.03 & 0.08 & 0.20 & $\mu \mathrm{g} / \mathrm{l}$ \\
\hline
\end{tabular}




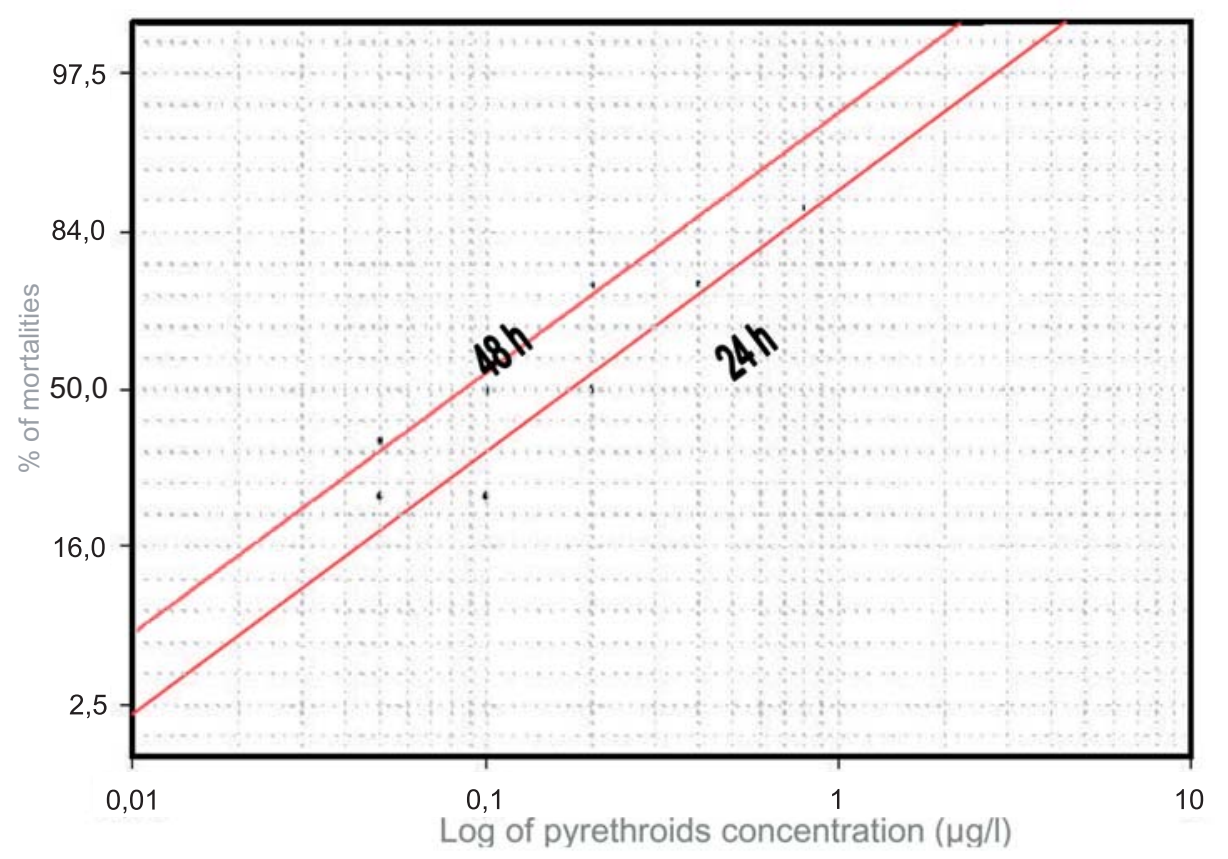

Figure 4

Example of dose-effect curve (probit) for the evaluation of pyrethroid's LC50 on crayfish.

Figure 4

Exemple de la courbe dose/effet (probit) pour l'évaluation de la LC50 des pyréthroïdes sur des écrevisses.

The lowest concentrations that caused death in crayfish were:

- Cypermethrin $=0.04 \mu \mathrm{g} / \mathrm{l}$.

- Deltamethrin $=0.06 \mu \mathrm{g} / \mathrm{l}$.

- Cyfluthrin $=0.06 \mu \mathrm{g} / \mathrm{l}$.

Neurological symptoms such as loss of coordination of movements and paralysis were observed before the crayfish death.

The average LC50-24h values were:

- Cypermethrin $=0.16 \mu \mathrm{g} / \mathrm{l}$ (confidence limits 0.08-0.32 $\mu \mathrm{g} / \mathrm{l}$ ).

- Deltamethrin $=0.22 \mu \mathrm{g} / \mathrm{l}$ (confidence limits $0.12-0.44 \mu \mathrm{g} / \mathrm{l})$.

- Cyfluthrin $=0.17 \mu \mathrm{g} / \mathrm{l}$ (confidence limits 0.08-0.33 $\mu \mathrm{g} / \mathrm{l}$ ).

The average LC50-48h values were:

- Cypermethrin $=0.10 \mu \mathrm{g} / \mathrm{l}$ (confidence limits 0.05-0.23 $\mu \mathrm{g} / \mathrm{l})$.

- Deltamethrin $=0.18 \mu \mathrm{g} / \mathrm{l}$ (confidence limits $0.09-0.35 \mu \mathrm{g} / \mathrm{l})$.

- Cyfluthrin $=0.08 \mu \mathrm{g} / \mathrm{l}$ (confidence limits $0.03-0.20 \mu \mathrm{g} / \mathrm{l})$. 


\section{Long term (24 d) toxicity test in Cyprinus carpio}

No mortality was recorded in the group of fish treated for 24 days at the concentration one hundred times higher than the LC50-24h.

\section{Evaluation of pyrethroids residues in fish and crayfish}

None of the samples of muscle plus adherent skin examined had pyrethroid concentrations above the limit of quantification ( $L O Q=50 \mu \mathrm{g} / \mathrm{l}$ for Deltamethrin; $\mathrm{LOQ}=10 \mu \mathrm{g} / \mathrm{I}$ for Cyfluthrin and Cypermethrin) of the GC-method employed (Tables IV-V). Figure 5 presents a chromatogram of Deltamethrin in tissues of common carp.

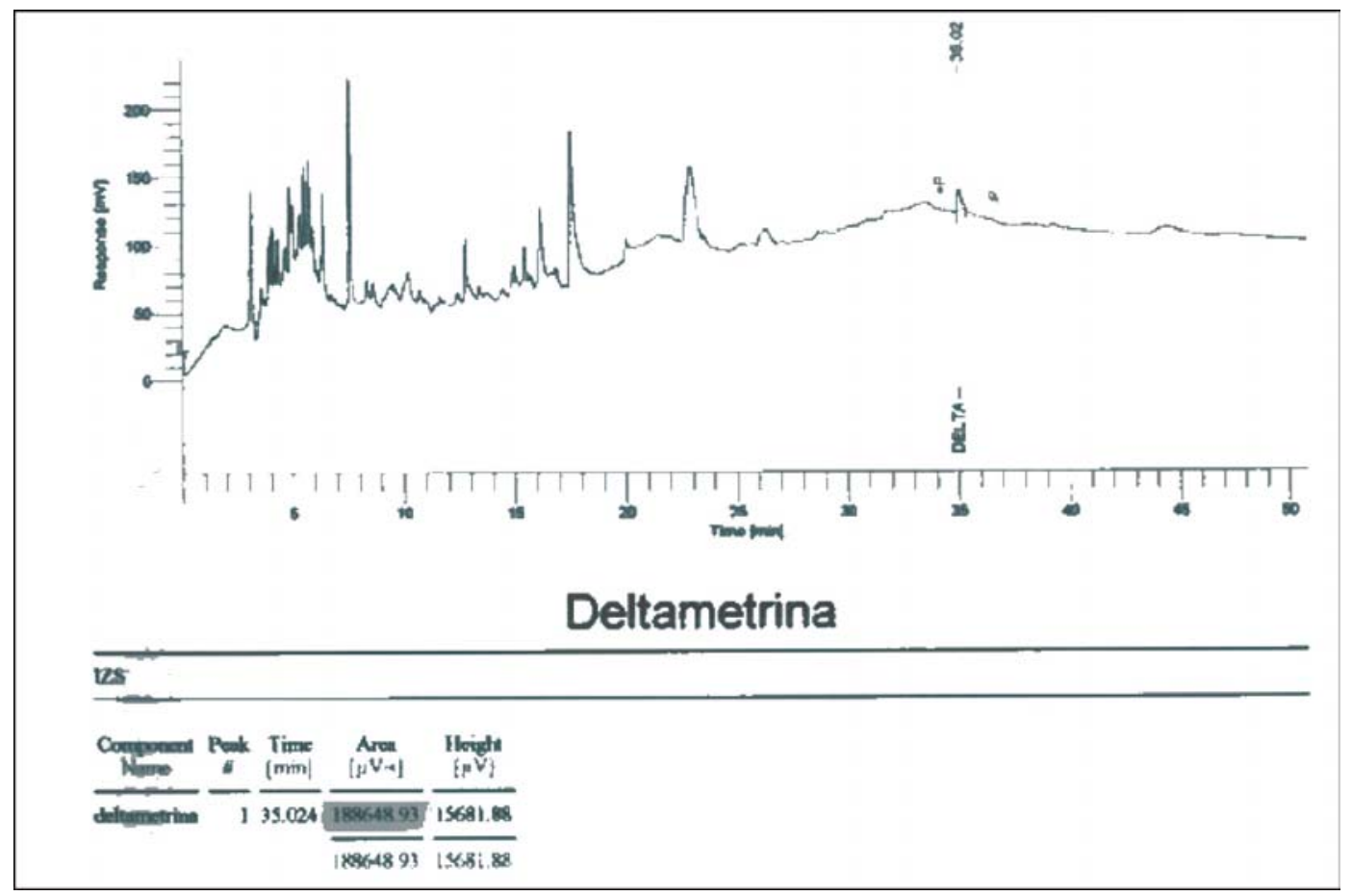

Figure 5

Example of chromatogramm for the evaluation of Deltamethrin concentration in tissue of fish.

\section{Figure 5}

Exemple de chromatogramme pour l'évaluation de la concentration en Deltaméthrine dans le tissu des poissons.

\section{DISCUSSION}

Organophosphate, pyrethroid insecticides, rotenone and surfactants were investigated for crayfish control/eradication (CABRAL et al, 1996; CHANG and LANGE, 1967; EVERSOLE and SELLER, 1997; HENDRICK, EVERETT and CAFFEY, 1966; HOLDICH, GYDEMO and ROGERS, 1999; LAURENT, 1995; RAY and STEVENS, 1970).

Synthetic pyrethroids have a high toxicity for freshwater crayfish, inducing neurological symptoms such as loss of coordination of movements, paralysis and death of crayfish; QUAGLIO et al (2000) observed, in laboratory toxicity tests on red swamp crayfish, average LC50 $24 \mathrm{~h}$ values of Cyfluthrin of $0.13 \mu \mathrm{g} / \mathrm{l}$. 
The results of the present study show that all the pyrethroids examined are strong toxicants, as very low concentrations resulted in high mortality in crayfish. In particular, Cypermethrin shows the highest acute toxicity (lower value of LC50-24h, average $=0.16 \mu \mathrm{g} /$ I) and Cyfluthrin looks very toxic too: LC50-24h value is very low (average $=0.17 \mu \mathrm{g} / \mathrm{l}$ ). These pyrethroids have a good residual activity with LC50-48h values similar to each other (Cypermethrin $=0.10 \mu \mathrm{g} / \mathrm{l}$; Cyfluthrin $=0.08 \mu \mathrm{g} / \mathrm{l}$ ). The value of LC50-24h for Deltamethrin is slightly higher comparing to the other pyrethroids (average $=0.22 \mu \mathrm{g} / \mathrm{l}$ ). Moreover, the LC50-24h and LC50-48h (average $=0.18 \mu \mathrm{g} / \mathrm{l}$ ) are similar: the power of this pyrethroid appears to decrease more rapidly in water than other products, as indicated in the characteristics shown in Tables I-III.

Acute and chronic toxicity studies show that the synthetic pyrethroids are highly toxic to fish and aquatic invertebrates and moderately toxic to algae. Aquatic acute toxicity values for Cyfluthrin include a rainbow trout 96 -hour LC50 of $0.68 \mathrm{ppb}$, a bluegill 96-hour LC50 of $1.5 \mathrm{ppb}$ and a daphnia 48-hour EC50 of $0.14 \mathrm{ppb}$ (USEPA/OPP, 1993). According to KNAUF and SCHULZE (1977, reported in WHO 1990) the values LC50-96h for Deltamethrin, tested as formulated product on Cyprinus carpio, range from 0.86 to $210.0 \mathrm{ppb}$. In our study, the results of toxicity test on young carp with Deltamethrin showed that this product didn't induce lethal effects in fish, at a concentration 100 times more than the LC50-24h for crayfish $(22.0 \mu \mathrm{g} / \mathrm{l})$.

According to HOLDICH, GYDEMO and ROGERS (1999), ecosystem recovery is fairly rapid with the toxic effect of pyrethroids and recolonisation of stillwaters and short stretches of river by natural flora and fauna can be expected (HILEY, 2003).

Pyrethroids have rapid lethal effects on crayfish, inducing an irreversible effect following the alteration of nervous impulses transmission and a rapid death. The active ingredient induces the death, acting rapidly on the nervous system, with low possibility of accumulation in other tissues. Our results show that no accumulation of pyrethroids in tissues resulted in fish and crayfish. The very low level of Deltamethrin (lower than LOQ) in muscle and skin of treated fish could be caused by the rapid degradation and/or rapid elimination of this biocide in or from analysed fish tissues.

The environmental fate and degradation of pyrethroid insecticides were reviewed in 1979 by LEAHEY. In the field, the metabolites of pyrethroids are all esters and are rapidly degraded, both by macroscopic and microscopic organisms. Consequently, they do not persist in the environment for long periods and apparently they do not accumulate in the biosphere. Synthetic pyrethroid insecticides are not expected to biomagnify through the food chain, due to their high sorption and immobilization in soil and because they are rapidly eliminated from tissue after the end of exposure (SPEHAR, TANNER, NORDLING, 1983). All the biocides used in the aquatic natural environment are subjected to several different factors that negatively influence their toxic action:

- dilution and dispersion,

- sedimentation (in particular pyrethroids that have low water solubility),

- organic matter or sediment chelation,

- photolysis,

- isomerization and degradation.

The LC50 values obtained in our experimental test can be considered as a starting point for field trials to verify the real toxic effects on crayfish and the potential for eradication of unwanted populations. 


\section{CONCLUSIONS}

The tested synthetic pyrethroids Cyfluthrin, Deltamethrin and Cypermethrin were confirmed as having good characteristics for the control of nuisance populations of crayfish. The values of LC50-24h and LC50-48h are rather low and the selectivity tests on fish demonstrated that fish are more resistant.

Heavy loss of aquatic life should be expected within the modest and clearly defined area over which control is exercised.

Despite their properties, toxic effects can be expected in some sensitive organisms and short duration exposure toxicity tests should be conducted to properly assess the impacts.

Further works will be required to study the potential effects that accumulated compound in sediments may have on benthic and planktonic communities and in order to ensure that environmental effects could be reliably limited to the target area, using readily available chemicals.

The use of the pyrethroids assayed in this research could be suggested for crayfish control/eradication only in limited areas (such as rice fields and fish farming), and more detailed research and development would take place first in the laboratory then on a small scale in field, before a working method was attempted in a larger water area.

More studies are, however, needed to understand the impact of the environment parameters listed above on the toxicity of the pyrethroids before starting the in-field experimentation.

\section{ACKNOWLEDGEMENTS}

The research was supported by grants from Regione Emilia Romagna, L. 28/98.

\section{REFERENCES}

CABRAL J.A., ANASTACIO P.M., CARVALHO R., MARQUES J.C., 1996. A non harmful chemical method of red swamp crayfish, Procambarus clarkii, population control and non target organism problematic in the lower Modego River valley, Portugal. Freshwater Crayfish, 11, 286-292.

CHANG V.G.S., LANGE W.H., 1967. Laboratory and field evaluation of selected pesticides for control of the red crayfish in California rice fields. Journal of Economic Entomology, 60 (2), 473-477.

EVERSOLE A.G., SELLER B.C., 1997. Comparison of relative crayfish toxicity values. Freshwater Crayfish, 11, 274-285.

HENDRICK R.D., EVERETT T.R., CAFFEY R.H., 1966. Effects of some insecticides on the survival, reproduction and growth of the Louisiana red crawfish. Journal of Economic Entomology, 59 (1), 188-192.

HILEY P.D., 2003. Field application of biocides for signal crayfish control. In HOLDICH D.M. \& SIBLEY P.J. (eds) (2003). Management \& Conservation of Crayfish. Proceedings of a conference held on 7th November, 2002. Environment Agency, Bristol, 185199.

HOLDICH D.M., GYDEMO R., ROGERS W.D., 1999. A review of possible methods for controlling nuisance populations of alien crayfish. Crustacean issues, 11, Eds GHERARDI F. \& HOLDICH D.M., pp. 8, 245-270. 
KNAUF W., SCHULZE E.F., 1977. Effect of decamethrine on Cyprinus carpio, Frankfurt, Hoechst AG, 9 p. (Unpublished proprietary report 15/77, submitted to WHO by Roussel Uclaf), In: WHO, 1990.

LAURENT P.J., 1995. Eradication of unwanted crayfish species for astacological management purposes. Freshwater Crayfish, 8, 121-133.

LEAHEY J.P., 1979. The metabolism and environmental degradation of the pyrethroid insecticides. Outlook on Agriculture, 10, 135-142.

LITCHFIELD J.T., WILCOXON, 1949. A Simplified method of evaluating dose-effect experiments. J. Pharmacol., 96, 99-113.

QUAGLIO F. MALVISI J., MAXIA M., MOROLLI C., DELLA ROCCA G., DI SALVO A. Toxicity of synthetic pyrethroid Cyfluthrin to the red swamp crayfish (Procambarus clarkii). Freshwater Crayfish, 13, 431-436.

RAY J., STEVENS V., 1970. Using Baytex to control crayfish in Ponds. Prog. Fish-Cult, 32 (1), 58-60.

SPEHAR R.L., TANNER D.K., NORDLING B.R., 1983. Toxicity of the synthetic pyrethroids, permethrin and AC 222,705 and their accumulation in early life stages of fathead minnows and snails. Aquat. Toxicol., 3, 171-182.

USEPA/OPP, 1993. Support Document for the Addition of Chemicals from Federal Insecticide, Fungicide, Rodenticide Act (FIFRA) Active Ingredients to EPCRA Section 313. U.S. Environmental Protection Agency, Washington, DC (1993). As cited by US EPA in: Federal Register: January 12, 1994. Part IV. 40 CFR Part 372. Addition of Certain Chemicals; Toxic Chemical Release Reporting; Community Right-to-Know; Proposed Rule.

WHO, 1990. International programme on chemical safety. Environmental Health Criteria 97 Deltamethrin. http://www.inchem.org/documents/ehc/ehc/ehc97.htm 